\title{
Membangun Kemandirian Finansial Pribadi dan Umat
}

\section{(RECONSTRUCTION OF THE INDEPENDENCE PERSONAL FINANCE AND THE PEOPLE)}

\author{
Laily Dwi Arsyianti ${ }^{1}$ \& Irfan Syauqi Beik ${ }^{2}$ \\ Program Studi Ekonomi Syariah, FEM IPB \\ Jl. Raya Darmaga Bogor \\ E-mail: laily@yahoo.com
}

\begin{abstract}
Life in the world not only involves compulsory worship but also social relations. Our interest in social relationships is to build a prosperous people in the world and in the Hereafter, as well as our task which has been determined as a vicegerent on earth. This article tries to explain the steps that need to be taken to develop the independence both personally and in the unity of the people, from the financial side. This financial capital which became one person and Muslims widely, to help the robustness of the buildings and the revival of the Ummah. Therefore, in the end we can stand on its own without depending on any party that can control us and may be misleading the people.
\end{abstract}

Keywords: Finance, Independence, Islamic Economics

\begin{abstract}
Abstrak: Kehidupan di dunia bukan hanya melibatkan ibadah mahdhoh melainkan juga muamalah. Kepentingan kita dalam bermuamalah adalah untuk membangun umat yang sejahtera di dunia dan di akhirat, sebagaimana tugas kita yang telah ditentukan sebagai khalifah di muka bumi. Artikel ini mencoba menjelaskan langkah-langkah yang perlu ditempuh untuk membangun kemandirian baik secara pribadi maupun dalam kesatuan umat, dari sisi finansial. Finansial inilah yang menjadi salah satu modal seorang pribadi dan umat Muslim secara luas, untuk membantu kekokohan bangunan dan kebangkitan umat. Oleh karena itu, pada akhirnya kita dapat berdiri sendiri tanpa tergantung kepada pihak manapun yang dapat mengendalikan kita dan dapat menjerumuskan umat.
\end{abstract}

Kata Kunci: Finansial, Kemandirian, Ekonomi Islam

\footnotetext{
${ }^{1}$ Dosen Ekonomi Islam Universitas Ibn Khaldun Bogor dan Program Studi Ekonomi Syariah, FEM, IPB, Pengasuh Rubrik Konsultasi Keuangan AULIA.

${ }^{2}$ Dosen pascasarjana Universitas Ibn Khaldun Bogor dan Program Studi Ekonomi Syariah FEM IPB. Pengasuh Rubrik Konsultasi Republika Online dan Iqtishodia Harian Republika
} 


\section{Pendahuluan}

Dan hendaklah takut kepada Allah orang-orang yang seandainya meninggalkan di belakang mereka generasi yang lemah yang mereka khawatir terhadap mereka. (QS

An-Nisa:9)

Ibnu Katsir dalam tafsirnya, mengaitkan ayat tersebut dengan kunjungan Rasulullah SAW kepada Tholhah menanyakan kepada Rasulullah tentang rencananya untuk mewasiatkan (memberi harta bukan kepada ahli waris) seluruh hartanya, namun Rasulullah SAW melarangnya. Tholhah kemudian menurunkan porsi menjadi $1 / 2$ harta dan Rasulullah SAW pun masih melarangnya. Rasulullah SAW baru mengizinkan ketika Tholhah mengusulkan untuk mewasiatkan $1 / 3$ hartanya. Kemudian Rasulullah bersabda bahwa meninggalkan generasi yang kuat secara ekonomi itu jauh lebih baik dari pada meninggalkan anak-anak dalam kondisi lemah dan meminta-minta.

Namun, jangan disalahartikan bahwa ayat dan hadist di atas mendorong kita untuk memupuk harta sebanyak-banyaknya agar dapat diwariskan kepada ahli waris kita. Lebih dari itu, ayat ini mendorong kita berlomba-lomba untuk meginfakkan harta sebanyak-banyaknya, sehingga kita akan dapat membina generasi selanjutnya menjadi lebih baik, lebih kuat dan lebih bermanfaat untuk umat.

Mari kita telusuri sejarah hidup Rasulullah SAW. Beliau sudah berada dalam kondisi yatim piatu sejak sebelum menginjak usia 10 tahun. Allah mengkondisikan Rasulullah SAW hidup dalam asuhan kakek dan kemudian pamannya. Ketika dalam asuhan pamannya, beliau tidak berpangku tangan atau menjadi pengangguran, melainkan beraktifitas sebagai penggembala kambing.

Pada usia remaja, beliau mengembangkan diri menjadi seorang pedagang internasional dan kembali menunjukkan keteladanan finansial. Bahkan sebelum menikah dengan Ummul Mukminin, Khadijah ra, beliau telah melakukan perjalanan internasional sebanyak belasan kali. Sehingga ketika menikahi Khadijah ra, mas kawinnya adalah 100 ekor unta muda yang pada saat itu dianggap sebagai kendaraan terbaik. Mungkin dalam analogi sekarang, unta-unta tersebut diibaratkan dengan kendaraan sekelas Audi r8 di Indonesia konon berharga 5 milyar rupiah. 
Mengenal kondisi Rasulullah SAW yang sangat terbatas kehidupan ekonominya, bahkan beliau sempat harus berpuasa sunnah karena di rumah istrinya tidak ada makanan, terjadi setelah beliau diutus menjadi Nabi. Kondisi tersebut adalah sebuah pilihan, bukan keterpaksaan, sementara beliau adalah seorang pedagang hebat, begitu pula istrinya, Khadijah ra.

Dari ayat, hadist, dan kisah Rasulullah di atas dapat dikatakan bahwa memiliki kemandirian finansial adalah sebuah keniscayaan. Dengan kemandirian finansial, kita bisa memberikan manfaatan sebanyak-banyaknya kepada masyarakat dan lingkungan sekitar kita, bahkan mungkin hingga ke 'ujung' dunia. Oleh karena itu, pemasalahan yang dikaji pada artikel ini adalah langkah apa yang dapat ditempuh untuk dapat membangun kemandirian secara finansial? Sehingga, tujuan artikel ini adalah dapat menjawab pertanyaan tersebut.

\section{Metode}

Literatur buku dan artikel ditelusuri untuk mengkaji berbagai langkah potensial untuk membangun kemandirian finansial. Oleh karena itu, kajian yang dilakukan lebih mendekati metode kualitatif secara deskriptif. Dalam pembahasan digambarkan langkah yang diperlukan sesuai urutan dan merupakan kesatuan untuk mencapai kesimpulan.

\section{Pembahasan}

“Dan carilah apa yang telah dianugerahkan Allah kepadamu (kebahagiaan) negeri akherat; dan janganlah kamu melupakan kebahagiaanmu dari (kenikmatan) duniawi dan berbuat baiklah (kepada orang lain) sebagaimana Allah telah berbuat baik kepadamu, dan janganlah kamu berbuat kerusakan di (muka) bumi. Sesungguhnya Allah tidak menyukai orang-orang berbuat kerusakan." (QS 28:77)

Ayat tersebut memberikan beberapa rambu penting agar kita tidak salah memaknai kehidupan dan kaitannya dengan kemandirian finansial.

\section{Pertama; Akhirat tetap yang sama}

Usahakan setiap kali kita memperoleh pendapatan, sisihkan sebagian untuk membersihkan harta kita. Jika belum mencapai nasib zakat, maka kita bisa mengeluarkan infak. Jika belum mencapai nisab zakat, maka kita bisa 
mengeluarkan infak. Bukan lantas berdalih belum mencapai nisab sehingga tidak mengeluarkan infak sedikitpun. Anggaplah jika kita berzakat maka kita memperoleh nilai $\mathrm{C}$, sehingga standar minimal kita adalah zakat, untuk mencapai yang lebih tinggi kita perlu berinfak/bersedekah sebanyakbanyaknya.

\section{Kedua; Dunia tidak dilupakan}

Seringkali kita salah mengartikan zuhud. Istilah tersebut jangan diartikan kita berdiam tidak berusaha dan hidup dalam keadaan bersusahsusah, menerima apa adanya. Zuhud adalah menjadikan dunia di tangan, bukan di hati. Kita boleh memiliki harta dan kekayaan, karena dengannya kita dapat memberikan manfaat untuk orang lain. Sebagaimana hadist Rasulullah SAW bahwa sebaik-baik manusia adalah yang paling bermanfaat untuk orang lain. Yang paling nyata misalnya adalah membuka kesempatan kerja untuk orang lain, sehingga untuk menjadi demikian kita memerlukan modal. Dan selanjutnya, kita harus berusaha agar kekayaan tersebut tdak mengendalikan hati dan keimanan kita.

\section{Ketiga; Berbuat baik sebagaimana Allah berbuat baik kepada kita}

Mungkin akan dirasa sulit jika kita memberi kepada orang yang pelit. Tetapi kita perlu mencoba untuk berbuat baik kepada siapa pun tanpa memandang sifatnya. Allah saja mau memaafkan kesalahan-kesalahan kita, kenapa kita yang hanya ciptaan-Nya menolak untuk berbuat baik, mungkin saja kebaikan kita, orang yang pelit tersebut tergerak hatinya dan berubah menjadi seorang yang pemurah.

\section{Keempat;Tidak berbuat kerusakan}

Berbuat kerusakan ini sangat luas dimensinya. Termasuk pula ke dalamnya adalah berusaha memperoleh pendapatan melalui jalan yang batil, korup, dan menggunakan instrument yang dilarang oleh Allah dan RasulNya, seperti bunga atau riba, judi dan sebagainya. Setelah mengetahui

pentingnya sebuah kemandirian finansial, selanjutnya kita kaji bagaimana cara mencapainya.

\section{Kelima; Mulailah dengan visi besar yang Allah ridhai}

Visi diperlukan untuk mengarahkan kehidupan kita. Maka segala sesuatu yang kita lakukan, ditujukan untuk mancapai visi itu. Visi yang dituju haruslah besar tanpa batas, kecuali syariat Allah SAW yang membatasinya. 
Visi besar dibutuhkan agar kita pun dapat berbuat sebanyak-banyaknya untuk kesejahteraan masyarakat hingga ke 'ujung' dunia atau langit sekalipun. Jika visi kita besar, maka tujuan-tujuan kecil bisa tercapai sebanyak-banyaknya.

Seseorang yang bercita-cita ingin menyejahterakan masyarakat dengan memperkerjakan orang sejumlah 500 ribu orang dari seluruh dunia maka ia pun tidak akan menyepelekan kondisi lingkungan karena menyejahterakan masyarakat berarti menjaga lingkungan agar tetap rapih, bersih dan nyaman untuk dihuni. Semakin banyak masyarakat yang ingin disejahterakan, semakin banyak lingkungan yang dilestarikan dan terjaga. Bandingkan dengan seseorang yang bercita-cita hanya ingin memperkerjakan 5 orang, maka hanya lingkungan itu saja yang diperhatikan.

Seseorang yang bercita-cita ingin menyejahterakan petani dan peternak Indonesia, maka dia bisa berzakat, berinfak, dan berinvestasi sebanyak-banyaknya sekaligus sehingga dia termotivasi memiliki atau mengelola modal sebanyak-banyaknya untuk mencapai apa yang diinginkannya. Bandingkan jika cita-citanya yang ingin menyejahterakan petani dan peternak di ligkungan pedesaannya saja, maka zakat, infak, dan investasinyapun sebatas itu.

\section{Keenam; Menyukai "memberi" dibandingkan "menerima"}

Pendekatan ini menghidarkan kita dari sifat pelit. Hanya dengan dalih berhemat kita tidak mau membayarkan ongkos tetangga atau teman yang bersama-sama kita naik kendaraan umum. Dengan dalih batasan pengeluaran sudah melebihi anggaran, namun pada kenyataannya masih ada sisa untuk ditabung, kita menolak menerima tamu dari jauh untuk berkunjung ke rumah kita. Jika ingin berhemat, kurangilah pemenuhan kebutuhan yang bisa kita nikmati sendiri, misalnya untuk berhemat listrik, kurangi menonton tv atau mematikan lampu yang tidak terpakai di siang hari, atau kurangi frekuensi ke salon untuk creambath atau perawatan kecantikan lainnya, ataupun jika manfaatnya tidak signifikan maka tidak perlu latah membeli handphone jenis tertentu kalau khawatir disebut 'ga gaul' cukup tahu teknologinya.

Dengan demikian setiap kali kita mendapat rezeki pendapatan/penghasilan baik tetap ataupun tidak tetap, kita akan senantiasa merasa ada kewajiban yang harus dipenuhi dahulu sebelum kita menikmati hak kita. Kebiasaan memberi akan melatih kita berempati sekaligus memotivasi kita untuk berusaha meningkatkan kemandirian finansial agar 
bisa memberi lebih banyak lagi, tanpa menghiraukan hak kita yang layaknya dinikmati sendiri. Menyukai "memberi" memotivasi kita untuk produktif dan berusaha menghasilkan sesuatu untuk diberikan kepada orang lain. Sifat ini juga dapat menjadi tabungan kita di kehidupan setelah dunia nanti.

\section{Ketujuh; Kreatif}

Don't put all your eggs in one basket menuntut kita untuk kreatif berproduksi. Sehingga jika kurang berhasil berproduksi di satu usaha maka tidak mudah putus asa dan kreatif membuka yang lain. Hal ini dibutuhkan karena bukan hanya kita sendiri yang menjadi tanggung jawab kita melainkan juga keluarga dan pegawai yang menjalankan usaha bersama kita. Oleh karena itu, kita tidak mungkin membiarkan mereka menganggur dan tidak mendapatkan apa-apa melainkan tanggung jawab kita untuk memberi kesejahteraan kepada mereka, memberi pekerjaan kepada mereka.

Untuk itu, kita perlu menyusun berbagai rencana A, B, C, D, sebanyakbanyaknya. Jika rencana $A$ kurang berhasil, masih ada rencana $B$, rencana $B$ kurang berhasil, ada rencana $C$, jika belum berhasil juga, ada rencana $D$, dan demikian seterusnya. Usahakan terus berkreasi membuat berbagai rancangan atau rencana yang feasible.

\section{Kedelapan; Mencari dan menangkap peluang}

Untuk mencari peluang yang kita butuhkan adalah memperluas networking atau jaringan kita. Dengan kata lain, membuka silaturahim sebanyak-banyaknya dengan orang lain, termasuk dengan orang yang tidak dikenal. Salah satu caranya adalah menyampaikan salam terlebih dahulu kepada orang lain sekalipun yang belum kita kenal. Dengan demikian, mungkin saja pintu rezeki atau peluang usaha ataupun peluang mendapatkan penghasilan akan terbuka dan begitu terbuka, secepatnya kita raih. Tangkap sebanyak-banyaknya peluang yang sudah dihadapan mata.

Hindari berkata "tidak" terhadap peluang, atau menciptakan berbagai alasan untuk tidak menerima peluang. Sekalipun bukan bidang kita atau bahkan tidak ada pengetahuan kita atas peluang yang ditawarkan, menangkap peluang tersebut adalah lebih baik karena kita menjadi belajar sehingga kemudian menjadi tau dan lama kelamaan bukan tidak mungkin malah kita menjadi expert di bidang tersebut. jangan lupa, kita diwajibkan menyampaikan sesuatu meskipun hanya satu ayat. Namun demikian, bukan berarti kita menjadi sok tau atau berlagak mengetahui segala-galanya dengan 
menangkap peluang yang bukan bidang kita, sebaliknya justru kita dituntut belajar dan mencari pengetahuan sebanyak-banyaknya atas bidang tersebut. Jangan malu untuk bertanya kepada ahlinya.

\section{Kesembilan; Menghindari utang konsumtif yang tidak dapat ditanggung}

Utang konsumtif adalah utang yang ditujukan untuk memenuhi kebutuhan pribadi yang habis terpakai atau tidak menghasilkan. Contoh utang konsumtif adalah mempengaruhi utang kartu kredit untuk belanja makan di restoran, utang membeli rumah untuk dihuni, utang membeli mobil atau motor untuk transportasi sehari-hari, utang membeli perobatan rumah atau furniture untuk dinikmati di rumah, dan utang-utang sejenisnya yang ditujukan hanya untuk memenuhi keinginan sesaat untuk status dan gaya hidup di masyarakat.

Akan tetapi, utang dapat digunakan untuk kepentingan produktif atau berinvestasi. Contoh utang seperti ini adalah utang untuk membeli mobil yang akan direntalkan, membeli rumah untuk dijadikan sarang walet atau koskosan, membeli komputer untuk perlengkapan wartel atau warnet, dan utangutang sejenisnya yang dimanfaatkan dengan baik.

Dengan begitu, kita bisa memilah-milah kebutuhan berdasarkan prioritas. Misalnya, jika uang yang dibutuhkan untuk membeli sofa tamu belum mencukupi, maka jangan dipaksakan berhutang. Meski resikonya adalah harus menerima tamu dengan gaya lesehan atau kita bisa berdalih seperti gaya Jepang. Uang yang belum mencukupi itu lebih baik diinvestasikan untuk usaha yang produktif sehingga menghasilkan sesuatu yang lebih bermanfaat untuk lebih banyak orang, misalnya untuk membeli kambing yang bisa digembalakan tetangga di kampong kita atau untuk diinvestasikan pada usaha teman pengusaha yang sedang membutuhkan dana.

Jika membutuhkan dana, usahakan utang menjadi alternatif paling akhir karena utang akan menghambat seorang yang syahid untuk menikmati syurga Allah. Begitu dahsyatnya utang, sehingga seseorang yang utangnya dibawa mati dan yang memberi utang tidak merelakannya, maka utangnya akan ditagihkan di akhirat kelak.

\section{Kesepuluh; Berdoa dan berusaha dengan sungguh-sungguh}

Terlepas apapun rencana kita, usaha kita, maka hasilnya tidak luput dari campur tangan Allah SWT. Dengan rahmat dan karunia dari Allah SWT- 
lah kita dapat melakukan aktifitas kita. Kita diberi kesehatan, diberi kesempatan, diberi tantangan, dan sebagainya nikmat yang mungkin tidak akan habis kita menghitungnya. Tidak seperti Qarun yang sombong karena mengira ilmunyalah yang menjadikan dirinya kaya dan melupakan peran Allah SWT seperti yang digambarkan dalam QS al-Qashas:78

“Dia (Qarun) berkata, "Sesungguhnya aku diberi (harta itu), semata-mata karena ilmu yang ada padaku". Tidakkah dia tahu, bahwa Allah telah binasakan umat-umat sebelumnya yang lebih kuat dari padanya, dan lebih banyak mengumpulkan harta? Dan orang-orang yang berdosa itu tidak perlu ditanya tentang dosa-dosa mereka."

\section{Penutup}

Dari pembahasan di atas dapat kita simpulkan bahwa jika ingin mencapai kemandirian finansial, beberapa langkah berikut perlu kita laksanakan: Mulailah dengan visi besar yang Allah ridhoi; Menyukai "memberi" dibandingkan "menerima"; Kreatif; Mencari dan menangkap peluang; Menghidari utang konsumtif yang tidak dapat ditanggung; Berdoa dan berusaha dengan sungguh-sungguh.

\section{Pustaka Acuan}

Al-Qur'an al-Karim. 2007. Syaamil al-Qur'an: Al-Qur'an dan Terjemahnya Special For Woman. Departemen Agama RI: didistribusikan oleh Sygma.

Antonio, M.S. 2007. Muhammad SAW: The Super Leader Super Manager, Cetakan I. Jakarta: ProLM Centre.

Arsyianti, L.D. dan Beik, I.S. 2010. Agar Muslimah Mandiri Finansial. ALIA No.11 Tahun VII Jumadil Awal-Jumadil Sani 1431/Mei 2010, hal. 66-70.

Hafidhuddin, D.2003. Islam Aplikatif, Jakarta: Gema Insani Press.

Hafidhuddin. D. 2007, Agar Harta Berkah dan Bertambah. Jakarta: Gema Insani Press.

Setiawan, I.R.2009. Islamic Financial planning: Dialog Taktis Menyiasati Krisis. Bandung: Salamadani Pustaka Semesta. 